\title{
Cloning and phylogenetic analyses of serine/ threonine kinase class defense-related genes in a wild fruit crop 'chestnut rose'
}

\author{
Qiang $X u^{*}$, Xiuxin Deng
}

\begin{abstract}
Background: Chestnut rose (Rosa roxburghii Tratt) is a promising wild fruit crop in Southwest China. However, chestnut rose suffers from several important diseases such as powdery mildew and black spot. Cloning and phylogenetic analysis of plant immunity related genes will strengthen the evolutionary knowledge of plant immune system and will facilitate the utilization of candidate genes in disease resistance breeding programs.

Findings: Serine/threonine kinase (STK) genes, encoding one of the important proteins for defense signal transduction, were cloned from 'chestnut rose'. Fifteen STK sequences were obtained by degenerate PCR. Sequence analysis showed that nine of them have continued open reading frames, and they are separated into five classes based on sequence analysis. Interestingly, one of the classes (STK V) showed less than $40 \%$ similarity to any other class, possibly representing new type genes from chestnut rose. Southern blotting analysis revealed that the new type STK $V$ genes are single copy, while all the other genes have several copies in the genome. Phylogenetic analysis of STK genes from chestnut rose and 21 plant species revealed that most chestnut rose genes show close relationship with Rosaceae homologs, while the STK V genes are rather ancient and form a unique clade distantly from plant homologs.

Conclusions: We cloned nine STK genes from a wild fruit crop 'chestnut rose', of which a new type of STK genes was identified. The new type STK genes exist as single copies in the genome, and they are phylogenetically distant to plant homologs. The polymorphic STK genes, combined with other plant immunity genes, provide plenty of resources to be utilized to defend against pathogens attack.
\end{abstract}

\section{Background}

Chestnut rose (Rosa roxburghii Tratt), a wild fruit crop in Southwest China, belongs to Rosaceae family Rosa genus. It has recently been labeled as one of the three promising new fruit crops in China due to its fruit having high content of vitamin C (2000-3000 mg/100 g FW), displaying high levels of superoxide dismutase (SOD) activity, and therefore is believed to have senescence-retarding and cancer-preventing effects [1]. Unfortunately, chestnut rose crops are suffering from powdery mildew disease. After decades of breeding, an indigenous cultivar from Guizhou province of China, Guinong No. 6, was discovered to be highly resistant to powdery mildew [2]. This material provides an opportunity to investigate the

\footnotetext{
* Correspondence: xuqiang@mail.hzau.edu.cn

National Key Laboratory of Crop Genetic Improvement, Huazhong Agricultural University, Wuhan 430070, Hubei, PR China
}

mechanism underlying the generation of the powdery mildew resistance specificity in chestnut rose.

Plants rely on their innate immune system to defend against pathogens. The immune system is composed of three important steps, i.e. pathogen detection, signal transduction, and defense response initiation [3-5]. The pathogen detection protein, encoded by resistance $(R)$ genes, can recognize pathogen-produced effectors and will produce a defense signal; the transmission and amplification of defense a signal requires kinase genes in the plant cell; finally the host initiates transcription of the defenseresponse gene including the pathogenesis-related $(P R)$ gene that can confer local or systemic resistance $[4,6]$.

Among the component genes of plant immune system, most researches are focusing on $R$ genes [7]. Many $R$ genes have now been cloned from a wide variety of plant species, of which the largest class is belonging to 
the nucleotide-binding site-leucine-rich repeats (NBSLRR) family $[7,8]$. The NBS domain is highly conserved across plant species, this characteristic facilitated the cloning of large number of sequences homologous to $\mathrm{R}$ genes, and so-called "R gene candidates (RGCs)", from many plant species by degenerate PCR strategy. Comprehensive analysis of plant RGCs have revealed that several important molecular events including duplication, recombination, mutation, strong balancing selection, diversifying selection, and meiotic instability occur on plant $R$ genes [9-11]. Compared with $R$ genes, research on other component genes of the plant immune system were rather limited.

Serine/threonine protein kinase (STK) is one of the important proteins responsible for defense signal transduction. The STK domain is the major constituent of the tomato Pto gene which not only interacts with the avirulence proteins from Pseudomonas syringae, but also functions as a signal transduction mediator [12]. The STK domain is also contained in the rice $X a 21$ gene which confers resistance to Xanthomonas oryzae pv oryzae [13]. STK domains are conserved across plant species, and have been isolated in several plant species by degenerate PCR [14-16]. Genome-level analysis of kinase genes were mainly carried out in Arabidopsis and rice [17-21]; and evolutionary analysis revealed that ancient diversification and rapid evolution occur on STK genes [22-24].

A great effort was taken to understand what happens to the immune system in parallel with the generation of the resistance specificity in the chestnut rose powdery mildew resistance genotype Guinong No.6 in our Lab. A total of 38 and 37 NBS-type resistance gene candidates (RGCs) were cloned from the resistant and susceptible genotype, respectively. Comparative analysis showed that the RGCs are under rapid evolution and are polymorphic between resistant and susceptible genotypes [25]. Moreover, genes corresponding to the defense response including pathogenesis related 2 (PR2) and PR5 gene families were cloned; sequence polymorphisms including single nucleotide differences and small insertion/deletions (InDel) were observed in these plant immunity genes. Through analysis of these two kinds of plant immunity genes, we discovered some information on the chestnut rose immune system. However, knowledge on the defense-related kinase genes is lacking. This prompted us to clone the STK kinase genes and investigate their sequence features, genomic status, and evolutionary characteristics in the chestnut rose powdery mildew resistance genotype.

\section{Methods}

\section{Plant materials}

Guinong No.6, a powdery mildew-resistant cultivar was used for STK genes cloning. Genomic DNA was extracted from $3 \mathrm{~g}$ samples of young leaves using a CTAB protocol from our Lab [26].

\section{Isolation of STK genes}

Degenerate primers were designed according to Di Gaspero and Cipriani [15] and Vallad et al., [14] targeted to isolate Serine/threonine kinase (STK) genes. Their sequences were: P3, TNGGNSANGGNGKNTTYGG; P8, AARYCNBMIAAYRTNCTICTNGAY; P2R, ACNCCRAANGARTANACRTC; P8R, TCNGGKCIAKRTAN CCNAKNGTNCC. PCRs were performed on a PTC-200 thermal cycler in a total volume of $50 \mu \mathrm{l}$ consisting of 50 ng DNA, $5 \mu \mathrm{l} 10 \times$ buffer (Promega), $5 \mu \mathrm{l} 10 \mathrm{mM}$ dNTP, $4 \mu \mathrm{l}$ of $25 \mathrm{mM} \mathrm{MgCl}, 2 \mu \mathrm{l}$ of $10 \mu \mathrm{M}$ primers and 2 units of Taq polymerase (Promega). The cycling conditions were as follows: $94^{\circ} \mathrm{C} 3 \mathrm{~min}$ followed by 32 cycles of $94^{\circ} \mathrm{C}$ $1 \mathrm{~min}, 55^{\circ} \mathrm{C} 1 \mathrm{~min}, 72^{\circ} \mathrm{C} 2 \mathrm{~min}$. PCR products corresponding to the expected size were excised from the gel and purified using a gel extraction column (Omega BioTek, USA). The obtained DNA fragments were cloned into pMD18-T vector (Takara Bio Inc.). Recombinant plasmid DNA was extracted by alkaline lysis. Each clone was re-amplified with M13 universal primers and then subject to restriction analysis using three restriction endonucleases (TaqI, HaeIII, and HinfI). Based on the restriction patterns, representative clones of each type were used for sequencing with the Bigdye Terminator V3.1 cycle sequencing kit on an ABI 3730 sequencer.

\section{Southern blotting analysis}

Southern blotting was performed according to Xu et al., [26]. Briefly, $10 \mu$ genomic DNA of Rosa roxburghii cv. Guinong No.6 and $R$. roxburghii cv. Guinong No.5 were digested with three different restriction endonucleases (i.e. HindIII, BamHI, and TaqI). Digests were separated by electrophoresis in a $0.8 \%(\mathrm{w} / \mathrm{v})$ agarose gel and transferred to Hybond-N+ membrane (Amersham). Hybridization was done at $65^{\circ} \mathrm{C}$ overnight. The stringency wash conditions were as follows: twice in $2 \times \mathrm{SSC} / 0.5 \% \mathrm{SDS}$ for $5 \mathrm{~min}$ at room temperature and once in $0.1 \times \mathrm{SSC} /$ $0.1 \% \mathrm{SDS}$ for $20 \mathrm{~min}$ at $65^{\circ} \mathrm{C}$. Membranes were exposed to $\mathrm{x}$-ray film at $-80^{\circ} \mathrm{C}$ for $2-6 \mathrm{~d}$.

Phylogenetic tree construction and tree similarity analysis Phylogenetic analyses were carried out according to $\mathrm{Xu}$ et al., [25]. Sequences from other plant species were downloaded from GenBank, and the detailed information on the representative genes can be viewed in Table 1. Sequences were aligned using CLUSTALX and manually edited in GENEDOC http://www.psc.edu/ biomed/genedoc/. Neighbor-joining trees using Kimura's two-parameter model and maximum parsimony phylogenetic trees were constructed and bootstrap number were calculated by heuristic search in PAUP* 4.0 
Table 1 Chestnut rose serine/threonine kinase (STK) gene homologs in different plant species ${ }^{a}$

\begin{tabular}{|c|c|c|c|}
\hline Source & STK Protein ${ }^{\mathbf{b}}$ & $\begin{array}{c}\text { Identity } \\
\text { (Similarity, \%) }\end{array}$ & e-value \\
\hline Arabidopsis thaliana & $\begin{array}{l}\text { NP_198220 } \\
\text { CAB62020 }\end{array}$ & $71(82)$ & $3 e-70$ \\
\hline Brassica rapa & AAZ66951 & $67(79)$ & $3 e-64$ \\
\hline Capsicum chinense & $\begin{array}{l}\text { AAQ82660 } \\
\text { AAQ82661 }\end{array}$ & $69(80)$ & $6 e-71$ \\
\hline Carica papaya & AAU81602 & $71(81)$ & $6 e-68$ \\
\hline Catharanthus roseus & CAA97692 & $68(80)$ & $2 e-70$ \\
\hline Cucumis melo & AAL83882 & $69(77)$ & $3 e-68$ \\
\hline Fragaria chiloensis & $\begin{array}{l}\text { ACA05210 } \\
\text { ACA05220 } \\
\text { ACA05215 }\end{array}$ & $69(79)$ & $1 e-69$ \\
\hline Lycopersicon pimpinellifolium & A49332 & $64(76)$ & $2 e-55$ \\
\hline Mangifera indica & AAT94935 & $67(78)$ & $1 e-67$ \\
\hline Marchantia polymorpha & BAF79940 & $71(80)$ & $9 e-73$ \\
\hline Medicago truncatula & ABE93789 & $72(81)$ & $4 e-76$ \\
\hline Musa acuminata & ABR68648 & $65(74)$ & $3 e-67$ \\
\hline Oryza sativa & $\begin{array}{l}X P \_476621 \\
E A \bar{Z} 36867\end{array}$ & $68(80)$ & $2 e-72$ \\
\hline Phaseolus vulgaris & AAK52027 & $60(74)$ & $1 e-69$ \\
\hline Physcomitrella patens & XP_001760779 & $72(82)$ & $4 e-71$ \\
\hline Potentilla tucumanensis & ACA05211 & $66(79)$ & $3 e-67$ \\
\hline Platanus $\times$ acerifolia & ACl05941 & $68(78)$ & $4 e-68$ \\
\hline Prunus avium & ABV30718 & $64(76)$ & $6 e-82$ \\
\hline Solanum lycopersicum & AAL17825 & $63(75)$ & $2 e-55$ \\
\hline Triticum aestivum & AAL51075 & $69(78)$ & $3 e-70$ \\
\hline Vitis vinifera & CAN60912 & 79 (87) & $6 e-80$ \\
\hline
\end{tabular}

${ }^{a}$ STK1 gene from chestnut rose was used for BLAST analysis.

${ }^{\mathrm{b}}$ Representative proteins chose from the STK proteins.

(Sinauer Associates, Sunderland, MA, USA). The trees were visualized using the program TREEVIEW http:// taxonomy.zoology.gla.ac.uk/rod/treeview.html.

\section{Results}

The cloning of serine/threonine kinase genes

With degenerate primer P3 and P2R pair, a band of the predicted size $(\sim 550 \mathrm{bp})$ was observed after PCR amplification with the DNA of powdery mildew resistant genotype (Guinong No.6) as a template (Fig. 1). These expected fragments were excised from agarose gel and cloned into the plasmid vector pMD18-T. A total of 170 positive clones were picked and used for screening by endonuclease restriction pattern. Thirty unique clones were chosen for DNA sequencing, of which 15 clones contained the primer sites. BLAST analysis against GenBank database revealed that the 15 genes are highly homologous to serine/threonine kinase (STK) genes (Table 1). Conceptual translations of the above 15 sequences revealed the presence of premature stop codons in six clones. These sequences

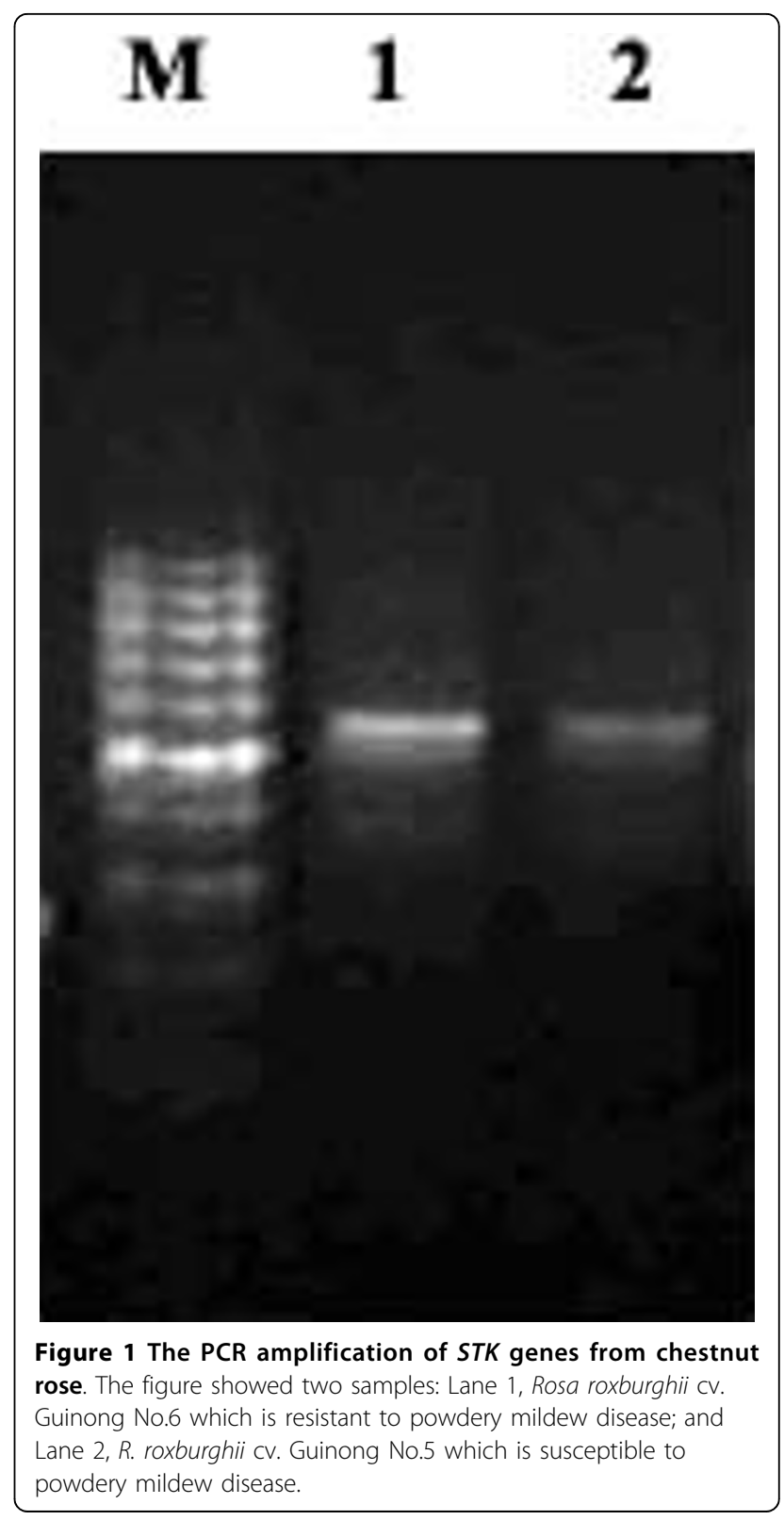

with in-frame stop codons are regarded as pseudogenes. The remained nine sequences (named as STK1-STK9 under Genbank accession number AY583621-AY583629) were regarded as STK genes by the presence of continue open reading frame (ORF) and by characteristic motifs such as VYKGVL and DVYSFG (Fig. 2).

For these nine sequences, nucleotide identity among each clone pair was determined. The identity ranged from 34-99\%, with the highest occurred between STK3 and STK4. The similarity of the deduced amino-acid of these nine sequences was also calculated (Table 2). Clones with greater than $85 \%$ similarity were grouped into a single class, and this resulted the nine sequences into five classes 


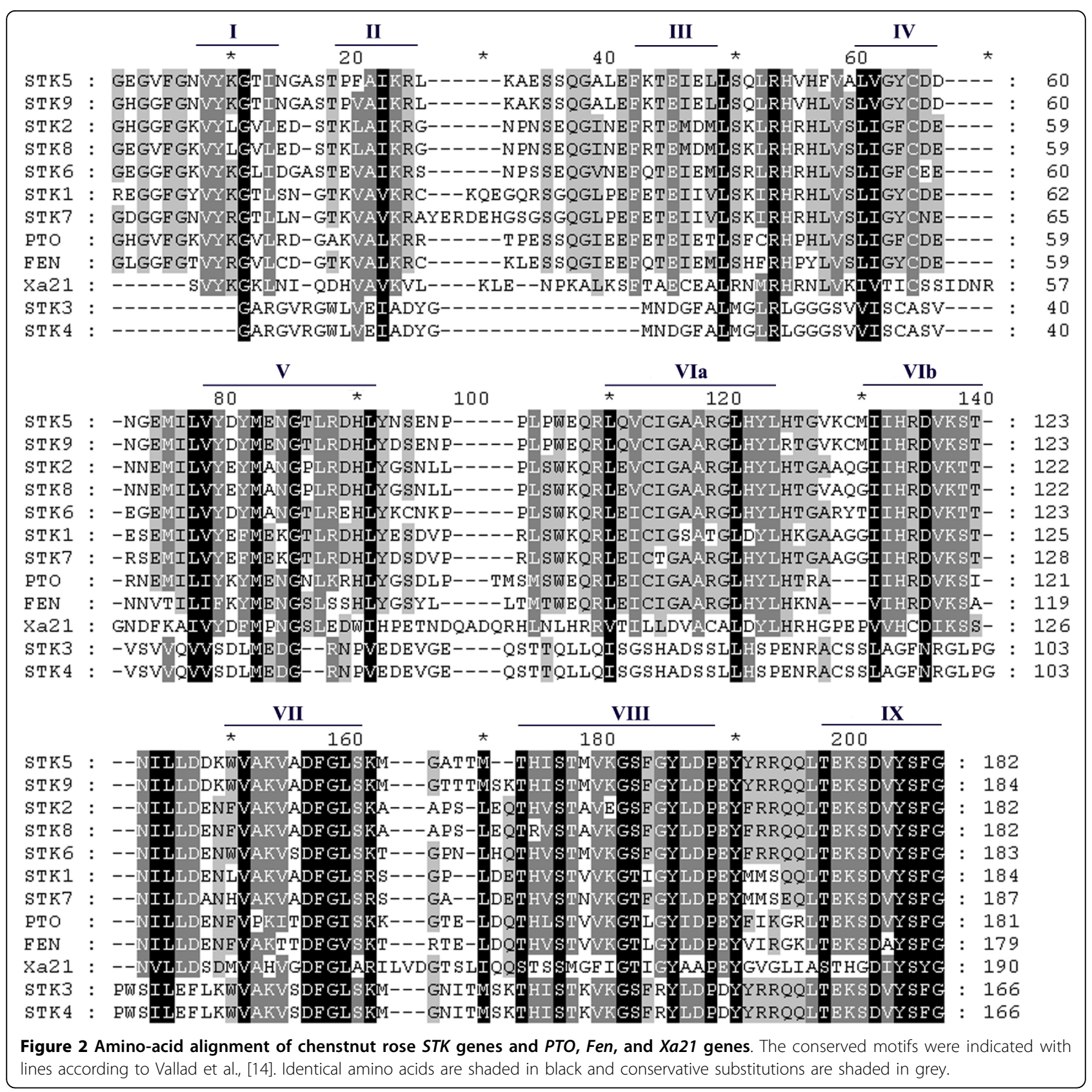

(designated as STK-I, STK-II, STK-III, STK-IV and STK-V). Amino-acid similarity among the classes ranged from $26 \%$ (STKI vs STKV) to 79\% (STKII vs STKIV).

It is surprising that STKV class (including STK3 and STK4 clones) showed less than $40 \%$ similarity to any other class. BLAST analysis of the STK3 and STK4 clones against GenBank database revealed that they are homologous to STK kinase gene with E-values $<\mathrm{e} \times 10^{-21}$, also the primer sites were contained in the two clones, assuring that they are STK kinase genes. The low similarity may suggest that STKV class is a new type of STK genes in chestnut rose genome.
Table 2 Percentage of amino-acid similarities among chestnut rose STK genes and the tomato Pto gene.

\begin{tabular}{lccccccccc}
\hline & STK1 & STK2 & STK3 & STK4 & STK5 & STK6 & STK7 & STK8 & STK9 \\
\hline STK2 & 68 & & & & & & & & \\
STK3 & 26 & 28 & & & & & & & \\
STK4 & 26 & 28 & 100 & & & & & & \\
STK5 & 62 & 67 & 32 & 32 & & & & & \\
STK6 & 68 & 79 & 31 & 31 & 72 & & & & \\
STK7 & 85 & 68 & 27 & 27 & 63 & 66 & & & \\
STK8 & 68 & 97 & 27 & 27 & 69 & 78 & 67 & & \\
STK9 & 63 & 69 & 34 & 34 & 94 & 73 & 64 & 68 & \\
Pto & 63 & 67 & 34 & 24 & 60 & 65 & 63 & 67 & 61 \\
\hline
\end{tabular}




\section{Southern blotting of chestnut rose STK genes}

Southern analysis of the chestnut rose STK genes revealed that the copy number of different genes varied greatly (Fig. 3). A number of copies were observed for STK1 and STK5 genes; while STK3, the new type of STK gene in chestnut rose genome, only had a single copy in the chestnut rose genome. Furthermore, no polymorphisms were detected between the powdery mildew resistant/susceptible genotypes using 3 probed genes (STK1, STK3, and STK5), as revealed by Fig. 3. This data indicated that different STK genes have different hybridization pattern but each STK gene was conserved among chestnut rose genotypes.

\section{Phylogenetic profile of chestnut rose STK genes}

Phylogenetic analysis was carried out using PAUP software according to $\mathrm{Xu}$ et al., [25]. The phylogenetic tree showed that chestnut rose nine STK genes were separated into five distinct clades (STKI-STKV), consistent with the similarity based amino-acid sequence analysis as described previously (Fig. 4).

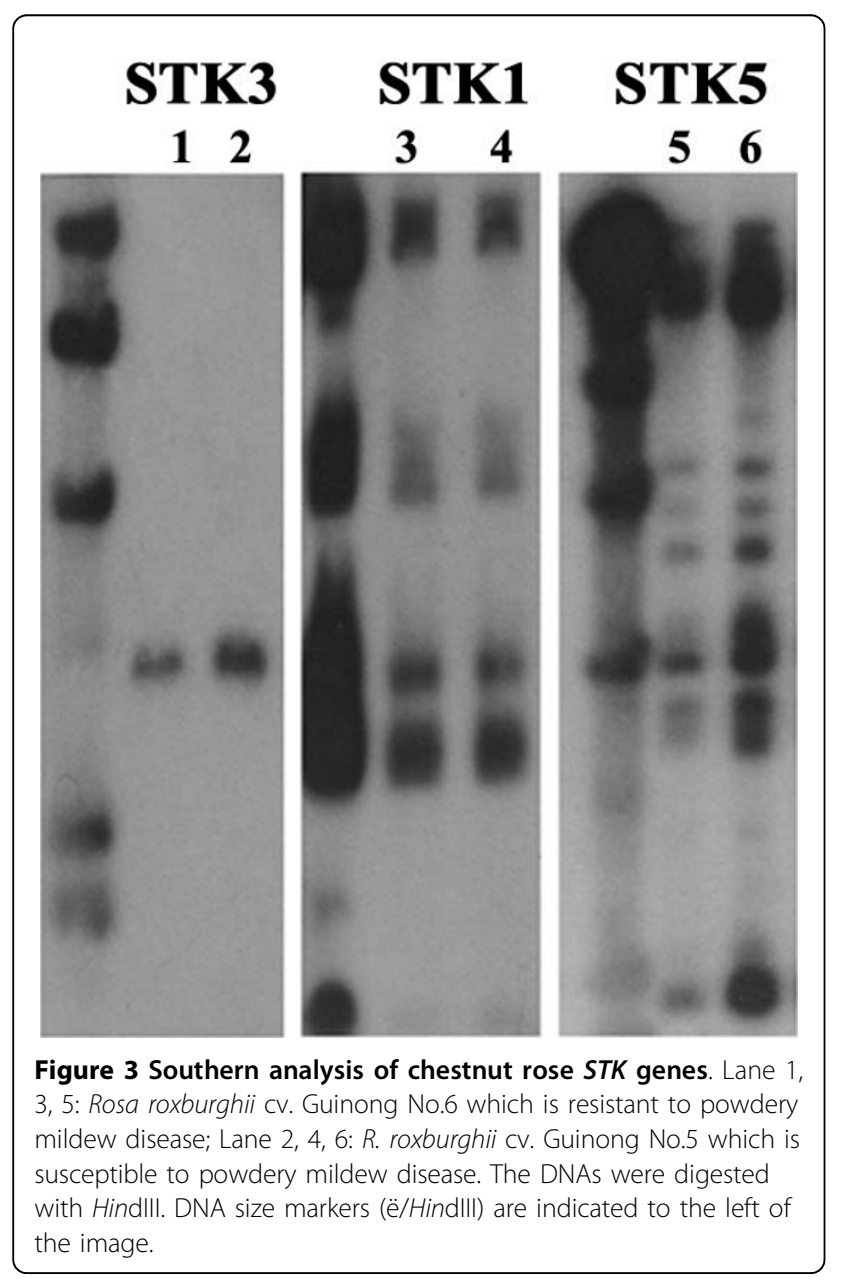

Evolutionary relationship among chestnut rose STK genes and other known STK genes was further evaluated by phylogenetic analysis. Amino acid sequences of chestnut rose STK genes were used as a query in BLASTp searches against GenBank database for possible homologues in other plants species. The top 100 sequences were selected, and highly homologous sequences ( $>85 \%$ identity) within a plant species were used to choose a representative sequence for further analysis. A total of 30 STK genes from 21 plant species were used in this study. The phylogenetic tree indicated that chestnut rose STK genes distributed in four clades; one was near to Platanus $\times$ acerifolia homolog, the second was neighbor to Vitis vinifera, the third was neighbor to Fragaria, and the final formed a distinct clade far from plant species but closely related with drosophila homolog gene (Fig. 5). These data suggested that the STK genes in chestnut rose are ancient with multiorigins.

\section{Discussion}

Defense against pathogens involves three important steps: pathogen detection, signal transduction, and initiation defense response [4]. Most of the previous molecular studies focus on the pathogen detection $R$ gene $[10,11,27]$. In this study, we characterized STK genes which encode kinase proteins responsible for the signal transduction during defense response. The genes from the relative wild fruit tree 'chestnut rose' showed close phylogenetic relationship to those from Rosaceae homologs after phylogenetic analysis of the STK genes from 21 plant species; however, some genes are a new type from chestnut rose. For example, STK3 and STK4 formed a unique clade which cannot be clustered with homolog genes from plants (Fig. 5). This indicates that from this wild fruit tree most of the STK genes are ancient and conserved, but with few plant-specific genes.

\section{The STK genes from a wild fruit crop 'chestnut rose'}

A total of 15 STK sequences were obtained from chestnut rose, of them nine have continue open reading frame. The nine genes have been separated into five classes based on both sequence similarity and phylogenetic analyses. Four of the five classes were belonging to known STK kinases, while the remained one class (STKV) represents a new type. The STK3 and STK4 genes (member of STKV class) showed less than $40 \%$ similarity to any other gene, and phylogenetic analysis showed that STKV class formed a unique clade which is more related with drosophila pelle gene than plant species STK genes. The low similarity observed among STKV class with other four STK classes is not rare case for plant immunity genes. For example, resistance $(R)$ gene, the other component of plant immune system, 


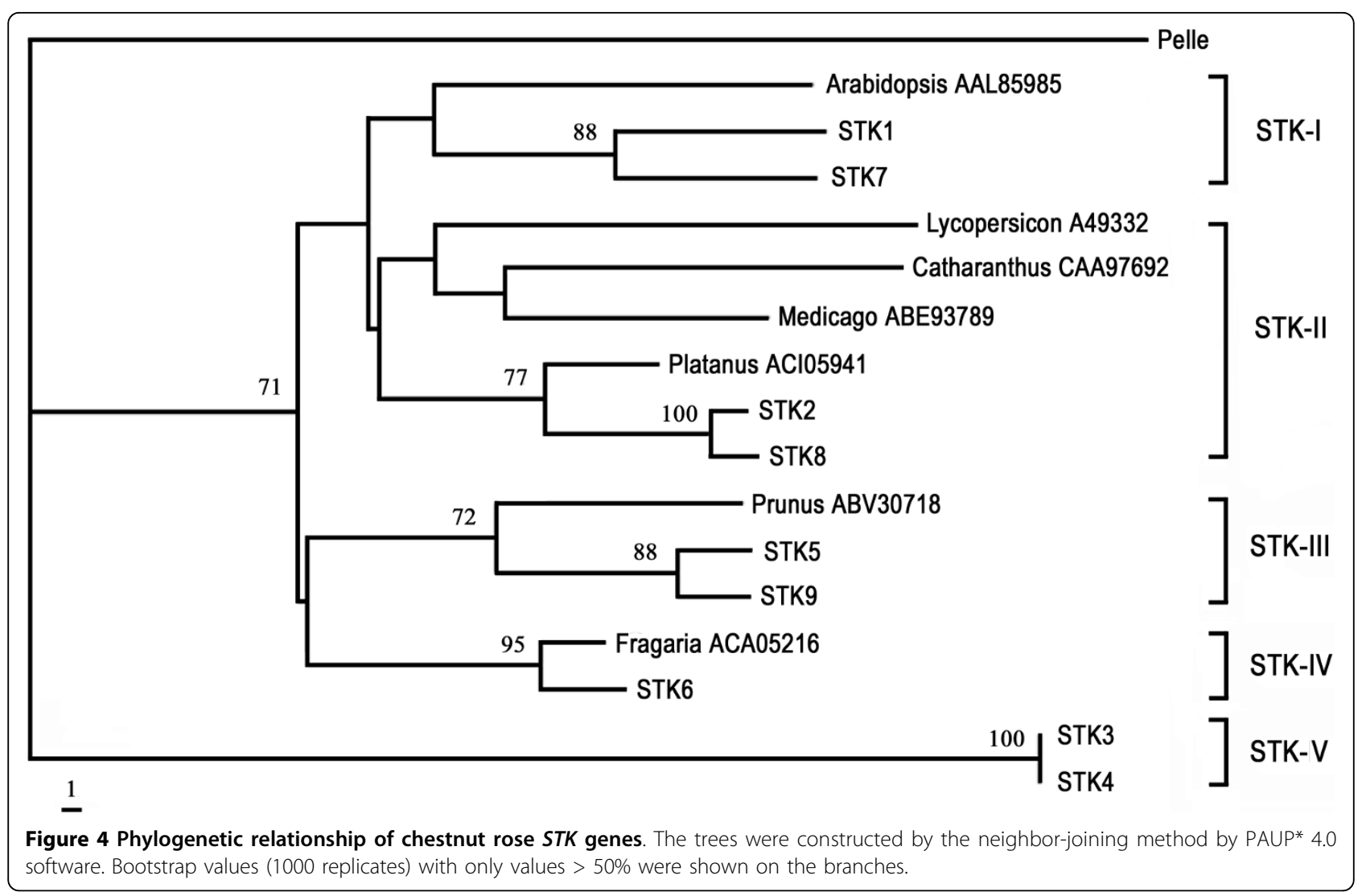

sometimes showed low sequence similarities. Resistance gene candidates (RGCs) sequence similarity ranged from 27 to $50 \%$ in Zingiber [28] and 19-44\% in lettuce [29]. These data suggests that $S T K$ gene, as well as $R$ genes, may exist in the genome long history and have diversified greatly during the long history evolution.

\section{Defense system in chestnut rose and its evolution}

From a powdery mildew resistant genotype of chestnut rose, the component gene of immune system, i.e. $R$-like gene, kinase genes, $P R$ genes, are all cloned $[25,26,30]$. In this study, we observed that STK2 and STK8 genes showed a close relationship with Pto Resistance gene, possibly indicated that they are candidate genes involved in the defense system in chestnut rose. When considering with the previous studies together, we found that for each plant immunity component gene many polymorphic members exist in the chestnut rose genome. This suggests that in the chestnut rose genome there is a sufficient resource of immunity genes utilized by plants to defend against pathogen attacks. Evolutionary analysis of these immunity genes also provided some clues on the complexity of plant immune system. Diversifying selection has been detected on RGC genes [25]; and for $P R 2$ genes diversifying selection is predominant [30] in chestnut rose. The genes under diversifying selection are believed to have strong function in the defense, suggesting that in chestnut rose PR2 and $R$ genes are actively involved in the immune responses which also require kinase gene for defense signaling. However, the immune system located in the plant cell is more complex than we can imagine. For example, there are more than 300 defensin-like genes in Arabidopsis [31]; many kinase genes such as Calmodulin-like domain protein kinases (CDPKs), and MAP kinases (MAPKs) were reported to be involved in defense activities [3,32]. Thus, plants can utilize enough strategies to defend against a pathogen invasion during the long time history.

\section{Conclusions}

From a wild fruit crop 'chestnut rose', serine/threonine kinase (STK) genes were cloned by degenerate PCR. Fifteen STK sequences were isolated, and nine of them have continued to open reading frames, and they are separated into five classes based on sequence analysis. One of the classes (STK V) showed less than 40\% similarity to any other new type of STK genes, and these new type STK genes exist as single copies in the genome, and they are phylogenetically related with animal homologs rather than plant homologs. The polymorphic STK genes, combined with other plant immunity genes, 


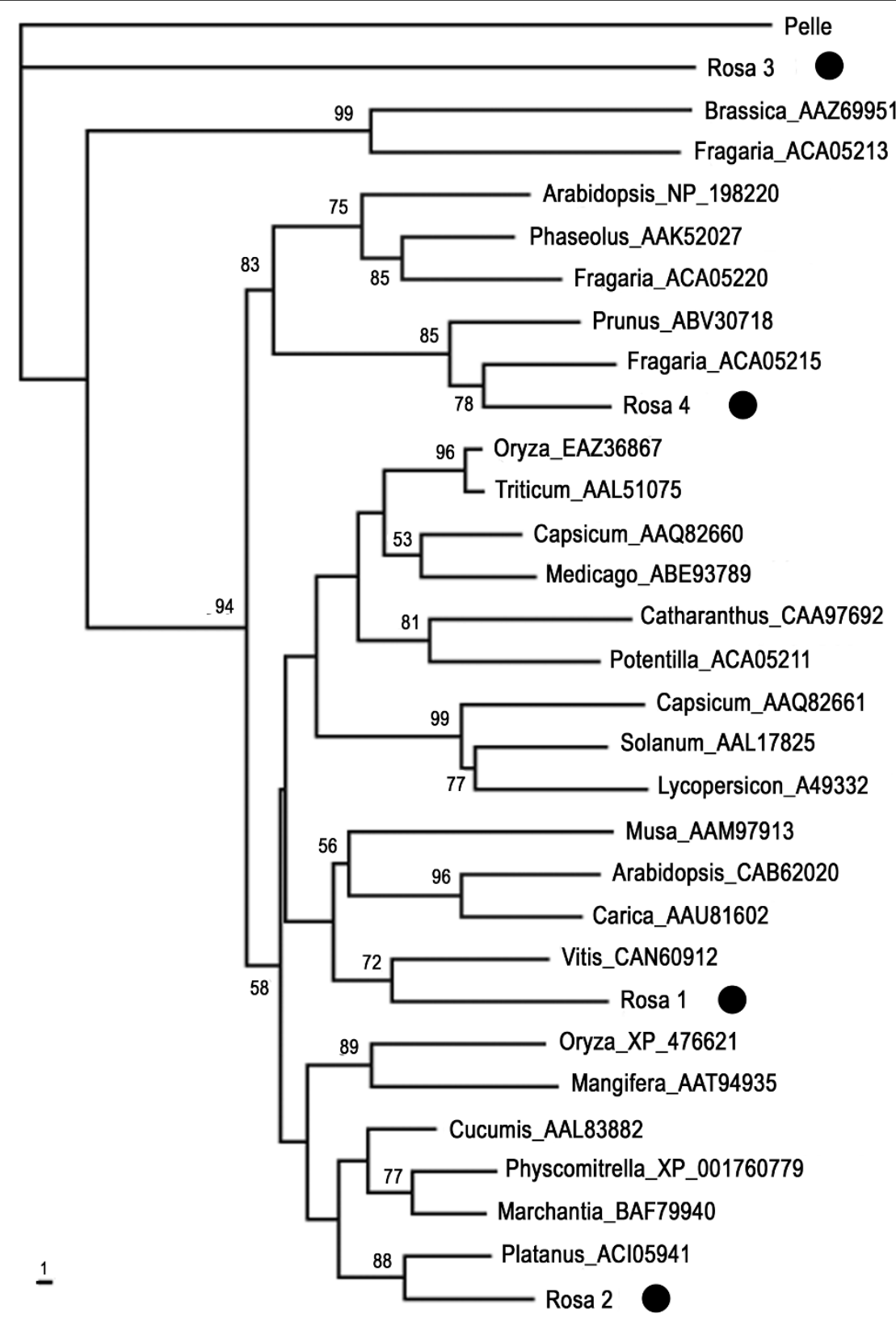

Figure 5 Phylogenetic relationship of $\mathbf{3 0}$ plant STK genes (4 from chestnut rose and $\mathbf{2 6}$ from other plant species). The STK genes from other plant species were based on the following strategy: amino acid sequences of chestnut rose STK genes were used as a query in BLASTp searches against GenBank database, the produced top 100 sequences were used for filter out highly homologous sequences (> 85\% identity) within a plant species. The remained sequences were used for phylogenetic analysis. Drosiphila Pelle gene was used as outgroup in this study. Rosa 1 comprises STK1 and STK7 genes; Rosa 2 comprises STK2 and STK8 genes; Rosa3 comprises STK3 and STK4 genes; Rosa4 comprises STK5, STK6 and STK9 genes. The trees were constructed by the neighbor-joining method by PAUP* 4.0 software. Bootstrap values (1000 replicates) with only values $>50 \%$ were shown on the branches.

provide sufficient resources for the plants to defend against pathogen attacks.

\section{Acknowledgements}

We thank Dominique Thomas for her language improvement. This project was supported by the National Science Foundation of China (NSFC no. 30800745), Specialized Research Fund for the Doctoral Program of Ministry of Education of China (No. 200805041024), Hubei Provincial Natural Science Foundation (2008CDB083), and the Fundamental Research Funds for the Central Universities.

\section{Authors' contributions}

QX and XXD designed the research. QX carried out experiments. QX drafted the manuscript. XXD proposed and supervised the research. All authors read and approved the final manuscript. 


\section{Competing interests}

The authors declare that they have no competing interests.

Received: 4 March 2010 Accepted: 18 July 2010 Published: 18 July 2010

\section{References}

1. Ma YX, Zhu Y, Wang CF: The aging retarding effect of 'Long-Life CiLi'. Mech Ageing Dev 1997, 96:171-189.

2. Wen $X, X u Q, C a o$ Q, Deng X: Promising genetic resources for resistance to powdery mildew in chestnut rose (Rosa roxburghii) and its relatives in China. New Zeal J Crop Hort 2006, 34:183-188.

3. Nimchuk Z, Eulgem T, Holt BF, Dangl JL: Recognition and response in the plant immune system. Annu Rev Genet 2003, 37:579-609.

4. Tiffin P, Moeller DA: Molecular evolution of plant immune system genes. Trends Genet 2006, 22:662-670.

5. Chisholm ST, Coaker G, Day B, Staskawicz BJ: Host-microbe interactions: shaping the evolution of the plant immune response. Cell 2006, 124:803-814

6. Bishop JG, Dean AM, Mitchell-Olds T: Rapid evolution in plant chitinases: molecular targets of selection in plant-pathogen coevolution. Proc Natl Acad Sci USA 2000, 97:5322-5327.

7. Jones JDG, Dangl JL: The plant immune system. Nature 2006, 444:323-329.

8. DeYoung BJ, Innes RW: Plant NBS-LRR proteins in pathogen sensing and host defense. Nature immunol 2006, 7:1243-1249.

9. Pan Q, Wendel J, Fluhr R: Divergent evolution of plant NBS-LRR resistance gene homologues in dicot and cereal genomes. J Mol Evol 2000, 50:203-213.

10. Bergelson J, Kreitman M, Stahl EA, Tian D: Evolutionary dynamics of plant R-genes. Science 2001, 292:2281-2284.

11. Geffroy V, Macadré C, David P, Pedrosa-Harand A, Sévignac M, Dauga C, Langin T: Molecular analysis of a large subtelomeric nucleotide-bindingsite leucine-rich-repeat family in two representative genotypes of the major gene pools of Phaseolus vulgaris. Genetics 2009, 181:405-419.

12. Martin GB, Brommonschenkel SH, Chunwongse J, Frary A, Ganal MW, Spivey R, Wu T, Earle ED, Tanksley SD: Map-based cloning of a protein kinase gene conferring disease resistance in tomato. Science 1993, 262:1432-1435.

13. Song WY, Wang GL, Chen $L L$, et al: A receptor kinase-like protein encoded by the rice disease resistance gene Xa21. Science 2009, 270:1804-1806.

14. Vallad G, Rivkin M, Ballejos C, Mcclean P: Cloning and hoology modeling of a Pto-like kinase family of common bean. Theor Appl Genet 2001, 103:1046-1058.

15. Di Gaspero G, Cipriani G: Nucleotide binding site/leucine-rich repeats, Pto-like and receptor-like kinases related to disease resistance in grapevine. Mol Gen Genomics 2003, 269:612-623.

16. Deng Z, Gmitter FJ: Cloning and characterization of receptor kinase class disease resistance gene candidates in Citrus. Theor Appl Genet 2003, 108:53-61

17. Shiu SH, Karlowski WM, Pan R, Tzeng YH, Mayer KF, Li WH: Comparative analysis of the receptor-like kinase family in Arabidopsis and rice. The Plant Cell 2004, 16:1220-1234.

18. Fritz-Laylin LK, Krishnamurthy N, Tor M, Sjölander KV, Jones JDG Phylogenomic analysis of the receptor-like proteins of rice and Arabidopsis. Plant Physiol 2005, 138:611-623.

19. Lehti-Shiu MD, Zou C, Hanada K, Shiu SH: Evolutionary history and stress regulation of plant receptor-like kinase/pelle genes. Plant Physiol 2009, 150:12-26.

20. Vij S, Giri J, Dansana PK, Kapoor S, Tyagi AK: The receptor-like cytoplasmic kinase (OsRLCK) gene family in rice: organization, phylogenetic relationship, and expression during development and stress. Mol Plant 2008, 1:732-750.

21. Ding $X$, Richter $T$, Chen $M$, et al: A rice kinase-protein interaction map. Plant Physiol 2009, 149:1478-1492.

22. Vleeshouwers VG, Martens A, van Dooijeweert W, Colon LT, Govers F, Kamoun S: Ancient diversification of the Pto kinase family preceded speciation in Solanum. Mol Plant-Microbe Interact 2001, 14:996-1005.

23. Peraza-Echeverria S, James-Kay A, Canto-canche B, Castillo-castro E: Structural and phylogenetic analysis of Pto-type disease resistance gene candidates in banana. Mol Genet Genomics 2007, 278:443-453.
24. Martinez Zamora MG, Castagnaro AP, Diaz Ricci JC: Genetic diversity of Pto-like serine/threonine kinase disease resistance genes in cultivated and wild strawberries. J Mol Evol 2008, 67:211-221.

25. Xu Q, Wen XP, Deng XX: Genomic organization, rapid evolution and meiotic instability of NBS-encoding genes in a new fruit crop "chestnut rose". Genetics 2008, 178:2081-2091.

26. $X u Q$, Wen XP, Deng XX: Isolation of TIR and NonTIR NBS-LRR resistance gene analogues and identification of molecular markers linked to a powdery mildew resistance locus in chestnut rose (Rosa roxburghii Tratt). Theor Appl Genet 2005, 111:819-830.

27. Cannon SB, Zhu H, Baumgarten AM, Spangler R, May G, Cook DR, Young ND: Diversity, distribution, and ancient taxonomic relationships within the TIR and non-TIR NBS-LRR resistance gene families. J Mol Evol 2002, 54:548-562.

28. Aswati Nair $\mathrm{R}$, Thomas $\mathrm{G}$ : Isolation, characterization and expression studies of resistance gene candidates from Zingiber spp. Theor Appl Genet 2007, 116:123-134.

29. Shen KA, Meyers BS, Islam-Faridi MN, Chin DB, Stelly DM, Michelmore RW: Resistance gene candidates identified by PCR with degenerate oligonucleotide primers map to clusters of resistance genes in lettuce. Mol Plant-Microbe Interact 1998, 11:815-823.

30. $X u Q$, Wen XP, Deng XX: Cloning of two classes of PR genes and development of SNAP markers for powdery mildew resistance loci in chestnut rose (Rosa roxburghii Tratt). Mol Breeding 2007, 19:179-191.

31. Silverstein KA, Graham MA, Paape TD, VandenBosch KA: Genome organization of more than 300 defensin-like genes in Arabidopsis. Plant Physiol 2005, 138:600-610.

32. Nurnberger T, Scheel D: Signal transmission in the plant immune response. Trends Plant Sci 2001, 6:372-379.

doi:10.1186/1756-0500-3-202

Cite this article as: $\mathrm{Xu}$ and Deng: Cloning and phylogenetic analyses of serine/threonine kinase class defense-related genes in a wild fruit crop 'chestnut rose'. BMC Research Notes 2010 3:202.

\section{Submit your next manuscript to BioMed Central and take full advantage of:}

- Convenient online submission

- Thorough peer review

- No space constraints or color figure charges

- Immediate publication on acceptance

- Inclusion in PubMed, CAS, Scopus and Google Scholar

- Research which is freely available for redistribution 